\title{
DIFFERENCES IN ASSESSING SELLERS' BEHAVIOUR BY THE CUSTOMERS OF BABY BOOM, $X, Y$ AND Z GENERATIONS
}

\author{
Jana Koval'ová ${ }^{1}, Z_{\text {Zuzana Birknerová }}{ }^{2}$, Miroslav Frankovský ${ }^{3}$, Eva Benková ${ }^{4}$
}

\begin{abstract}
The role of sellers is changing in a turbulent business environment and only the sellers who provide first class services and approach to them in a responsible way can survive among competitors. Customers perceive it as an added value and have a good feeling from buying. It is just sellers who are becoming the main factor that contributes to the competitiveness of a whole organization. The segmentation of customers into individual generations enables to better understand their preferences and requirements, it is then possible to predict their tendencies in buying behaviour and thus increasing the sales success. The main aim of the paper is to present the issue of different assessment of sellers' behaviour by the customers of Baby Boom X, Y, and Z generations. In connection with these differences, the aim of the research is to identify generational differences in the assessment of manipulative, assertive, stressed and engaged behaviour of sellers, as well as to analyse the determinants that affect buying behaviour of customers. The research was conducted using a questionnaire method and mathematical-statistical methods on the sample of 207 respondents. The research results confirm the existence of statistically significant differences in assessing the determinants of sellers' behaviour from the perspective of individual customer generations.
\end{abstract}

JEL Classification Numbers: M21, M31, DOI: 10.12955/cbup.v7.1358

Keywords: sellers' behaviour, generation Baby Boom, X, Y, Z, DOS-Z questionnaire

\section{Introduction}

The main aim of the paper is to present the issue of different assessment of sellers' behaviour by the customers of Baby Boom X, Y, and Z generations. In connection with these differences, the aim of the research is to identify generational differences in the assessment of manipulative, assertive, stressed and engaged behaviour of sellers, as well as to analyse the determinants that affect buying behaviour of customers.

Trade behaviour is according to Blackwell et al. (2006) a complex dynamic issue that is not easy to define and professional literature also provides conceptual ambiguity. In this context, it is appropriate to mention behavioural economy that represents the most general term within which trade behaviour, being its more specific term, takes place. By customers, we talk about buying behaviour, for sellers, it is selling behaviour. Trade behaviour is a mutual relationship between a customer and a seller in a trade environment, their mutual interaction and communication, with both parties displaying certain patterns of behaviour (Koval'ová, Birknerová, 2018).

Schiffman et al. (2012) define buying behaviour as a set of activities that include a purchase and the use of goods/services that are the results of customer's emotional and mental needs. According to Kotler (1994), it focuses on the following questions: what, how, when and why people buy things. Solomon et al. (2016) define it as processes in which individuals select, buy, use or have products, services, ideas, or experience at a disposal to meet their needs and desires. Kotler and Keller (2011) emphasize the significance of understanding customers' buying behaviour as well as the ways of selecting products and services that provide a competitive advantage for organizations. Kotler et al. (2012) describe the factors influencing buying behaviour as a cultural, social, personal, psychological factors as well as the customer himself/herself.

In the context of selling behaviour, sellers should realize the significance of a whole selling process (Eriksson, 2014; Rein, Purde, 2018). According to Lorincová et al. (2018), the role of sellers is not only taking and acquiring orders, communicating with customers or providing information about products. The key to the success in th trade environment among generations lies in analysing customers' feelings and emotions and providing them with what they need and want (Garton a Fromm, 2013).

In general, we can define behaviour as a way that an individual expresses himself/herself or behaves towards others in a society. In the trade environmnent, sellers express themselves by their selling behaviour and on the other hand, there are customers with their buying behaviour and according to Kokemuller (2017), it is just the professional sellers' behavior that is a key to the success. For the

\footnotetext{
${ }^{1}$ The University of Prešov in Prešov, Faculty of Management, Prešov, Slovakia, kovalova.jana@smail.unipo.sk

2 The University of Prešov in Prešov, Faculty of Management, Prešov, Slovakia, zuzana.birknerova@unipo.sk

${ }^{3}$ The University of Prešov in Prešov, Faculty of Management, Prešov, Slovakia, miroslav.frankovsky@unipo.sk

${ }^{4}$ The University of Prešov in Prešov, Faculty of Management, Prešov, Slovakia, eva.benkova@unipo.sk
} 
purposes of this research, four determinants that define different forms of sellers' behaviour were selected. We can generally divide individuals' behaviour into prosocial or ethical and undesirable or unethical behaviour. We consider prosocial behaviour to be assertive and engaged behaviour of sellers. The undesirable/unethical sellers' behaviour that has negative and demaging effect on the other individuals include manipulative and stressed sellers' behaviour.

\section{Baby Boom generations $\mathrm{X}, \mathrm{Y}$ and $\mathrm{Z}$}

As Mainland claims (2012), through the segmentation of customers, it is possible to acquire information enabling to create new products and services, to understand the different requirements and preferences or to know what customers apprieciate.

Segmentation of customers means their division according to similar characteristics that allows to ideintify the patterns of their behaviour, perception, attitudes, and preferences. The differences in trade behaviour among individual generations are dealt with in generational marketing that uses the generation segmentation in marketing communication (Fromm, Read, 2018; Garton, Fromm, 2013; Kumar, 2014; Bačík et al., 2018). Egan (2014) understands the term generation as a large internally differentiated group of people that is connected to a period conditioned by a similar way of thinking, behaviour or acting. Generation also means people within a delineated population, who experience the same significant events within a given period of time (Pilche, 1994); Robinson (2017). The definition of individual generations differs depending on a number of factors (culture, history, economy). Overlapping of interests and values can be expected at both ends of a generation spectrum.

The Baby Boom generation refers to people born during economic prosperity after World War II in the USA (1946 - 1964), also referred to as the postwar generation. They grew up in a stable period believing that they have political and social responsibility and can influence the world they live in (Hansen, Leuty, 2012). They value thorough work and diligence which they also appreciate on others (Gursoy et al., 2008). Their negative feature is avoiding changes and insufficient adaptability (Kane, 2010). Another weakness is that the majority of them cannot work with modern techologies at such a level as younger generations that is reflected also in a smaller awareness in buying. According to Lister (2018), they have the highest value on the market. They are loyal, want to know the value of a product especially without feeling any pressure from the sellers' side. They are able to spend the most and try to enjoy their savings.

For the purposes of this research, the determination of years for generation $\mathrm{X}$ is the range of customers born between 1965 - 1981. This generation highly values freedom and independence. They are competitive, self-assertive and hardworking, on the other hand individualistic and less loyal. They prefer balance between a working and private life. They were growing up without experience of online buying, they prefer buying in stone shops. But, according to Williams a Page (2011), they are also capable of using online purchases as they have accepted the Internet with a passion and turned their attention to the technologies of all kinds. This generation develops a great force at markets with media and technologies. And as stated by Wroblewski (2018), this is also the reason why generation X represents a certain "hybrid" in the area of generational marketing.

The customers of generation Y (1982-1992) are able to actively search (Horváthová, Čopíková, 2015), classify, filter and analyse (Hershatter, Eprstein, 2010) needed information. As presented by Broadbridge et al. (2007), this generation is more resistant and skeptical to traditional marketing tools and tactics as the previous generations. They actively respond to online shopping opportunities, they are more motivated to buying by the recommendations from a family and friends. They consider themselves as self-confident, flexible, direct, inventive, creative, ambitious and patient and they expect the same from sellers. As it is claimed by Prokopets (2017), the generation Y belongs to loyal customers when they are heard and well-cared for. According to Jenkins (2017), it is an era of demanding customers and so organizations should realize that they are only one click away from their competitors.

For the generation Z (1993-2010), technologies are still a natural part of their life and require a higher standard as the previous generations. Rao (2017) claims that there maybe a change in traditional patterns of organizational behaviour that were natural for the generation $\mathrm{X}$, as confirmed by a study conducted by the IBM Business Value Institute in 2017. As stated by Štefko, Fedorko and Bačík (2014), customers of younger generations like to connect to companies that are creating interactive environment where 
they can form their own experience. If organizations implement such practices, then they will be able to capture, utilize and implement ideas for products, services, or experience.

\section{Research}

The aim of the research was to find out whether there are statisctically significant differences in assessing the determinants of sellers' behaviour by the customers of generations Baby Boom X, Y and $Z$. The research continuously follows the theoretical elaboration of generational differences that was conducted through the original DOS-Z questionnaire: Determinants of Sellers' Behaviour for customers (Koval'ová, Birknerová, 2018). For the purposes of this research, the boundaries of the years for individual generations were set as follows: 1946-1964 Baby Boom, 1965-1981 generation X, 1982-1992 generation Y, 1993-2010 generation Z.

Using a questionnaire method, information was obtained from respondents and subsequently processed in a statistical programme SPSS 22. For the purpose of assessing the sellers by the customers, the original DOS-Z questionnaire was used: Determinants of trade behaviour for customers that consists of 48 products divided into four assessed determinants. Always 12 items analyse manipulative, engaged, stressed, and assertive sellers' behaviour. The respondents assess individual determinants with a Likert scale: 1 - definitely no, 2 - no, 3 - rather no than yes, 4 - rather yes than no, 5 - yes, 6 - definitely yes (Koval'ová, Birknerová, 2018).

\begin{tabular}{|c|c|c|c|c|c|c|}
\hline \multirow{2}{*}{ Items } & \multirow{2}{*}{ Generation } & \multirow{2}{*}{$\begin{array}{c}\text { Mean } \\
\text { Difference }\end{array}$} & \multirow{2}{*}{$\mathbf{F}$} & \multirow{2}{*}{ Sig. } & \multicolumn{2}{|c|}{ Mean } \\
\hline & & & & & 1. & 2. \\
\hline $\begin{array}{l}\text { If I feel being manipulated by a seller, I } \\
\text { feel negative emotions. }\end{array}$ & BB-Z & $.900 *$ & 2.499 & .038 & 3.42 & 4.32 \\
\hline \multirow{2}{*}{$\begin{array}{l}\text { If a seller provides me with high-quality } \\
\text { information about a product, the value of } \\
\text { the product increases as well for me. }\end{array}$} & BB-Y & $.782 *$ & \multirow[b]{2}{*}{4.890} & .024 & 4.17 & 4.95 \\
\hline & $\mathbf{Y}-\mathrm{Z}$ & $.598^{*}$ & & .023 & 4.95 & 4.35 \\
\hline $\begin{array}{l}\text { With a positive approach, a seller can } \\
\text { change customer's selection of a product. }\end{array}$ & BB-Y & $.807^{*}$ & 3.988 & .011 & 3.92 & 4.72 \\
\hline $\begin{array}{l}\text { When selecting a product, I get advised } \\
\text { from an engaged seller. }\end{array}$ & $\mathbf{X}-\mathrm{Z}$ & $.485^{*}$ & 3.665 & .024 & 4.78 & 4.30 \\
\hline $\begin{array}{l}\text { I appreciate a high level of engagement of } \\
\text { a seller. }\end{array}$ & $\mathbf{X}-\mathrm{Z}$ & $.529 *$ & 2.628 & .029 & 4.85 & 4.32 \\
\hline \multirow{2}{*}{$\begin{array}{l}\text { If a seller does not pay attention to me, I } \\
\text { leave the store. }\end{array}$} & BB-Z & $1.199 *$ & \multirow{2}{*}{4.405} & .006 & 4.18 & 2.98 \\
\hline & $\mathrm{X}-\mathrm{Z}$ & $.694 *$ & & .042 & 3.68 & 2.98 \\
\hline $\begin{array}{l}\text { If a seller ignores me, I search for a } \\
\text { competitive shop. }\end{array}$ & BB-Z & $.933^{*}$ & 2.207 & .050 & 4.42 & 3.48 \\
\hline \multirow{2}{*}{$\begin{array}{l}\text { If a seller is exposed to a stressful } \\
\text { situation, I take it into consideration. }\end{array}$} & BB-X & $.718^{*}$ & \multirow{2}{*}{3.266} & .037 & 3.67 & 4.38 \\
\hline & BB-Y & $.799 *$ & & .018 & 3.67 & 4.47 \\
\hline \multirow{3}{*}{$\begin{array}{l}\text { I respect when a seller is stressed, he/she } \\
\text { has a right to be. }\end{array}$} & BB-X & $1.183^{*}$ & \multirow{3}{*}{7.570} & .000 & 3.42 & 4.60 \\
\hline & BB-Y & $.721 *$ & & .037 & 3.42 & 4.14 \\
\hline & BB-Z & 1.033* & & .001 & 3.42 & 4.45 \\
\hline \multirow{3}{*}{$\begin{array}{l}\text { I do not like when a seller conveys stress } \\
\text { on customers. }\end{array}$} & BB-X & $1.522 *$ & \multirow{3}{*}{7.383} & .000 & 3.42 & 4.94 \\
\hline & BB-Y & $1.014 *$ & & .013 & 3.42 & 4.43 \\
\hline & BB-Z & $.983^{*}$ & & .017 & 3.42 & 4.40 \\
\hline $\begin{array}{l}\text { When shopping, I do not like when a } \\
\text { seller confines his problems to me. }\end{array}$ & BB-Y & $1.155^{*}$ & 3.451 & .008 & 3.50 & 4.66 \\
\hline $\begin{array}{l}\text { In a shop where I feel strees, I do not feel } \\
\text { comfortably. }\end{array}$ & BB-X & $.815^{*}$ & 2.974 & .022 & 4.00 & 4.82 \\
\hline \multirow{2}{*}{$\begin{array}{l}\text { I appreciate when a seller can resist } \\
\text { criticism fairly well. }\end{array}$} & $\mathbf{X}-\mathrm{Z}$ & $.458^{*}$ & \multirow{2}{*}{3.916} & .015 & 4.91 & 4.45 \\
\hline & Y-Z & $.447 *$ & & .023 & 4.90 & 4.45 \\
\hline \multirow{2}{*}{$\begin{array}{l}\text { I appreciate when a seller does not } \\
\text { apologise for things he/she cannot affect. }\end{array}$} & $\mathbf{X}-\mathrm{Z}$ & $.574 *$ & \multirow{2}{*}{3.764} & .012 & 4.91 & 4.33 \\
\hline & Y-Z & $.511 *$ & & .039 & 4.84 & 4.33 \\
\hline
\end{tabular}

Source: Authors

The research sample consisted of together 207 respondents, out of whom 87 were men (42\%) and 120 women $(58 \%)$ in the age of 18 to 67 years, with the average age of 35.34 years, (standard deviation 
12.52 years). From the generation $X$ (born in th period of 1965-1981), 65 (31.4\%) respondents were addressed, from the generation Y (born in the years 1982-1992), we addressed 58 (28\%) respondents and from the generation Z (born in 1993-2010), 60 (29\%) respondents were addressed.

In the research, we paid attention to finding out the differences in the assessment of sellers' behaviour determinants among four generations of customers: Baby Boom, X, Y and Z. Information obtained from the respondents was subsequently processed through the analysis One-Way ANOVA with Post Hoc Multiple comparisons with the use of Tukey Test, by using of which we were identifying the existence of statistically significant differences in the assessment of sellers' behaviour by the customers of particular generations. Statistically significant differences of individual items in the examined determinants from the point of view of generations are presented in Table 1.

Through the One-Way ANOVA analysis with Post Hoc Multiple comparisons using the Tukey test, we were identifying statistically significant differences among individual generations.

In the item "If I feel being manipulated by a seller, I feel negative emotions", the generation Z scored higher (4.32), approaching to an answer "rather yes than no". In contrary to BB generation that was inclined to answers "rather no than yes".

In responses to the statement "If a seller provides me with high-quality information about a product, the value of the product increases as well for me", the higher scores were given by the respondents of generation Y (4.95) inclined to the answer "yes", opposite to the generation BB (4.17) and Z (4.35), who preferred less exact answer "rather yes than no". Again, in the item "With a positive approach, a seller can change customer's selection of a product", the generation Y (4.72) scored the highest at a scale, contrary to the generation BB (3.92) who tend to less exact answer "rather yes than no". In the case of the item "When selecting a product, I get advised from an engaged seller", the generation X (4.78) get advised to a greater extent than the generation Z (4.30). Generation X (4.85) appreciate much more a high level of seller's engagement, opposite to the generation Z (4.32). Similarly, also in the item "If a seller does not pay attention to me, I leave the store", we recorded differences between generation BB-Z and X-Z. The highest scores were given by the oldest generation BB (4.18) who preferred the answer "rather yes than no", similarly also generation X (3.68), but the youngest defined generation scored considerably lower (2.96) that represents "rather no than yes". Based on these findings, we can state that older generation requires more attention.

In the analysed item "I respect when a seller is stressed, he/she has a right to be", we recorded statistically significant differences between generations $\mathrm{BB}$ and $\mathrm{X}, \mathrm{BB}$ and $\mathrm{Y}$, as well as BB and Z. Generation X scored the highest (4.60) with the answer "yes", so it appears like the most thoughtful. It is followed by generation Z (4.45) who answered at a boundary "rather yes than no" and "yes", then it is Y (4.14) who answered closest to the answer "rather yes than no" and surprisingly, the lowest scores were given by generation BB (3.42) who inclined to the answer "rather no than yes". We can state that generations X, $\mathrm{Y}$, and $\mathrm{Z}$ show a little bit more respect towards sellers who are in stress, than the oldest generation. However, the item "I do not like when a seller conveys stress on customers" confirms the existence of statistically significant differences. The average answer of generation BB (3.42) was approaching to the answer at a boundary „rather no than yes“, whereas generations X (4.94), Y (4.43) and Z (4.40) scored at a boundary between "rather yes than no" and "yes". We can state that probably all generations do not like when sellers convey stress on them. But based on the statements of older generation BB, we can confirm a little bit more respect and empathy towards sellers who were stressed, than by generations $X$, $\mathrm{Y}$ and Z. In the item "When shopping, I do not like when a seller confines his problems to me", the customers of BB generation scored lower (3.50) and their answer was at a boundary "rather no than yes" and "rather no than yes". But the generation Y (4.66) inclined to the unambiguous answer "yes". Based on this finding, we can assume that older generation seems to be a little bit more empathetic, on the contrary to younger generation Y. The customers of BB and Y generations indicated that "In a shop where they feel stress, they do not feel comfortably" while generation Y scored a little bit higher (4.82), opposite to BB (4.00).

In the item "I appreciate when a seller can resist criticism fairly well", we recorded statistically significant generational differences. The higher scores were given by generation X (4.91) a Y (4.90) who inclined to the answer "yes", opposite to generation Z (4.45) who indicated less ambiguous answer "rather yes than no". This claim shows a fact that generation X and Y appreciate when a seller is open 
and is able to resist unjustified criticism. Similar assessment was recorded in the item "I appreciate when a seller does not apologise for things he/she cannot affect", where generation X (4.91) scored the highest, followed by Y (4.84) and generation Z (4.33). Finally, we can state that the customers of generation X and $\mathrm{Y}$ appreciate a little bit more sellers' assertive approach in comparison to the youngest analysed generation $\mathrm{Z}$.

\section{Discussion and conclusion}

The aim of the paper was to present the issue of particular forms of sellers' behaviour that were assessed by the customers of generations Baby Boom X, Y, and Z. The research aim was to verify the existence of statistically significant differences in the assessment of selected sellers' behaviour determinants from the point of view of customers from individual generations.

The research was conducted through a quiestionnaire method using mathematical-statistical methods. The research sample consisted of total 207 respondents. Statistically significant differences were identified in 14 items of the DOS-Z questionnaire that reflect the determinants of manipulative, engaged, stressed, and assertive sellers' behaviour. Based on the research conducted, we found out that there are areas where the assessment of sellers by the customers of different generations differs.

Sunstein (2016) defines manipulation as something that does not sufficiently involve customers' skills to think and consult. That is why many customer decisions are taken without any rational thinking, on the other hand, they are increasingly becoming aware of motives and marketing tactics. Sellers struggle for customers' favour in a variety of ways, using psychological tools to keep customers' attention and motivate them to make purchase. As Koval'ová and Birknerová (2018) state, by sellers, manipulative behaviour occurs relatively often, as organizations focus on generating profit in which they are directly involved with their activities. They use unfair practices to achieve better sales results. Based on the results of the analysed items focused on customers feelings in manipulation by sellers, we can state that younger customers are more susceptible to manipulation.

According to Koval'ová and Birknerová (2018), engaged sellers behave towards an organization as to their own, they feel responsible for it, they want the organization to grow and make progress. They contribute to the growth of products and services quality, as well as to the increase of the value of the whole organization. They are willing to sacrify extra time and energy to achieve better results. Such sellers contribute to better customer experience by providing their quality services that is also confirmed in studies indicating that committed employers have productivity increased by $40-45 \%$. According to some authors (napr. Antonyová, et al., 2018; Madzík, et al., 2016; Rajnoha, et al., 2016 and others), the mentioned quality relates to well being, individual responsibility and high-quality information. Based on the research we conducted, we can state that by providing high-quality and relevant information about products, sellers can acquire customers' favour. For the youngest generations $\mathrm{Y}$ and $\mathrm{Z}$ analysed, even the product value increases for them by this approach. This finding is interesting because despite their quick access to information on the Internet, they can still appreciate the interaction "face-to-face" with a seller. We also focused on the reactions of customers whom the seller did not pay attention to. The customers categorized into $\mathrm{BB}$ generation were inclined to the response that they would leave the store, unlike the younger generation $\mathrm{Z}$ which would not leave the store for that reason. Based on this finding, it is obvious that these generations perceive seller's attention differently while the older generation requires more attention.

The issue of stress influence on sellers and their stressed approach to customers is dealt with by Allen (2017), according to whom, for every seller, a different situation can be stressful (new, demanding, dissatisfied, or passive customers, or the lack or excess of customers). As Kemp et al. (2013) present, stress at sellers' work can be useful but also harmful, depending especially on coping with the stress. The right type and level of pressure can contribute to motivation and productivity, on the contrary, an overdose acts as paralysing. As stated by Koval'ová, Frankovský, Birknerová and Zbihlejová (2018), happier and less stressed employers tend to be more productive, the communication level is better, thus increasing also the level of customers' satisfaction. The research of Malik et al. (2011) showed negative correlation between stress and satisfaction at work as well as a negative influence of stress on customers' satisfaction. Daniel et al. (2012) also emphasize the importance of employers' satisfaction that contributes to the organization growth and customers' satisfaction. In his research, Standford (2008) pays attention to the significance of employers' satisfaction at a workplace, as well as to the relationship 
between the satisfaction of employers and customers. Our research identified statistically significant generational differences in respecting and assessing a stressed seller. As already mentioned, it seems that all generations want to feel comfortably while shopping and therefore do not like when sellers convey stress and their problems on them.

Assertive behaviour manifests itself, according to Lelková and Gburová (2015), by open expressing, adequate communication, accepting others, establishing new relationships, making decisions and taking responsibility, compromises, awareness of own and others' rights or elimination of the feeling of being guilty and responsible for others. As stated by Koval'ová and Birknerová (2018), assertive sellers can communicate effectively, ask appropriate questions, listen to and solve problems, or they can apologise without offending customers, or making a bed reputation of an organization. Assertive care for customers respects their rights so that they get a good service or a product (Garnera, 2012). Based on the items analysed, focused on assertive approach of sellers, we can state that the generation $\mathrm{X}$ and $\mathrm{Y}$ appreciate when sellers are open and can defend themselves in the case of unjustified criticism a little bit more than the younger generation $\mathrm{Z}$ does.

Every generation of customers consists of unique personalities, of which it is obvious that not all will respond in the same way. Therefore, it is very important for sellers to realize this fact and based on this, to approach them individually.

We consider the low number of respondents being the limits of our research, and therefore plan to extend it in the future, as well as to add new determinants and personality characteristics.

\section{Acknowledgment}

VEGA 1/0807/19- Research on the determinants of trading behavior and marketing effects in the area of neuromarketing and the relation to neuro-linguistic programming

\section{References}

Allen, D. E. (2017). Keys To Delivering Amazing Customer Service. Houston: EAC Media.

Antonyová, A., Antony, P., Soewito, B., Abdullah, A. H. B. \& Nagapan, S. (2018). Reflection of Gross Domestic Product into the Income Values According to the Attained Level of Education in Europe. Advanced Science Letters. 24(12), 92619265.

Bačík, R., Fedorko R., Rigelský, M., Sroka, M. \& Turáková, A. (2018). Perceiving the advertising in gender-generational characteristics. Polish Journal of Management Studies. 18(1), 44-57.

Blackwell, R. D., Miniard, P. \& Emgel, J. (2006). Consumer behavior. Ohio: Thomson South-Western.

Broadbridge, M. A., Maxwell, G. A. \& Ogden, S. M. (2007). Students' views of retail employment - key findings from Generation Ys. International Journal of Retail \& Distribution Management. 35(12), 982-992.

Daniel, A., Ashar, M., Ihsan-Ur-Rehman, H. \& Shahbaz, W. (2012). An impact of employee satisfaction on customer satisfaction in service sector of pakistan. Journal of Asian Scientific Research. 2(10), 548-561.

Egan, J. (2014). Marketing Communications. London: Sage.

Eriksson, J. (2014). Building the sale process. Helsinki: Metropolia-University of Applied Sciences.

Fromm, J. \& Read, A. (2018). Marketing to Gen Z: The Rules for Reaching This Vast and Very Different Generation of Influencers. Amacom: Chicago.

Garner, E. (2014). Assertiveness. Re-claim your assertive brightright. Kindle edition

Garton, Ch. \& Fromm, J. (2013). Marketing to Millennials: Reach the Largest and Most Influential Generation of Consumers Ever. Amacom: Chicago.

Gursoy, D., Meier, T. A. \& Chi, Ch. (2008). Generational differences: An examination of work values and generational gaps in the hospitality workforce. International Journal of Hospitality Management. 27(3), 448-458.

Hansen, J-I. C. \& Leuty, M. E. (2012). Work Values Across Generations. Journal of Career Assessment. 20(1), 34-52.

Hershatter A. \& Eprstein, M. (2010). Millennials and the World of Work: An Organization and Management Perspective. Journal Of Business \& Psychology. 25(2), 211-223.

Horváthová P. \& Čopíková, A. (2015). Generation Y and its Impact on the Performance of Personnel Activities. International Scientific Conference on Globalization and its Socio-Economic Consequences. (p. 217-223). Slovakia: Rajecke Teplice.

Jenkins, R. (2017). The Millennial Manual: The Complete How-To Guide to Manage, Develop, and Engage Millennials at Work. Atlanta: Jenkins Publications.

Kane, S. (2010). Traditionalists (aka The Silent Generation). Retrieved January, 12, 2019, from http://legalcareers.about.com/ od/practicetips/a/Traditionalists.htm.

Kokemuller, N. (2017). What Is The Diference Between Ethical Business Practices and Legal Practices? Philosophical issues and ethical standards in business management a compilation. $47 \mathrm{p}$.

Kotler, P. \& Keller, K. (2011). Marketing Management. London: Pearson Education. 
Kotler, P. \& Armstrong, G. (1996). Principles of marketing. 7. Ed. Prentice Hall. 692 p.

Kotler et al. (2007). Moderný marketing. Praha: Grada Publishing. 4. Ed. 1041 p.

Koval'ová, J. \& Birknerová, Z. (2018). Determinanty obchodného správania z pohl’adu obchodníkov a zákazníkov. Prešov: Vydavatel'stvo PU.

Koval’ová, J., Frankovský, M., Birknerová, Z. \& Zbihlejová, L. (2018). Identification of links between sources and consequences of work-related stress. Ad Alta: Journal of interdisciplinary research 8(2), 65-69.

Kumar, P. (2014). Managing Career Aspiration of Generation Y-A Key to Business Excellence. Global Journal of Multidisciplinary Studies. 3(5), 13-17.

Lelková, A. \& Gburová, J. (2015). Asertivita v nákupnom správaní. Prešov: Bookman. 95 p.

Lister, M. (2018). Generational marketing: How to target Millennials, Gen X and Babyboomers. Retrieved January, 12, 2019, from https://www.wordstream.com/blog/ws/2016/09/28/generational-marketing-tactics.

Lorincová, T., Tomková, A. \& Suhányi, L. (2018). Prediction of selected personality characteristics of businessmen in the context of their potential to work with customer. International Journal of Organizational Leadership. 7(1), 99-105.

Mainland, B. (2012). Why you should segment your target market by generation. Retrieved January, 12, 2019, from https://www.dynamicbusiness.com.au/small-business-resources/starting/segmenting-your-target-market-via-generations20102012.html.

Madzík, P., Droppa, M., Daňková, A. \& Grigerová, A. (2016). Expected Level of State, Entrepreneurship and Individual Responsibility for Improving Quality of Life. Current Trends in Public Sector Research. Brno: Masaryk University, p. 293 301

Malik, M. I., Safwan, M. N. \& Sindhu, A. G. (2011). Examining stress, job satisfaction and customer satisfaction in a transport company (A case from Pakistan). International Journal of Business and Social Science. 2, 81-85.

Pilcher, J. (1994). Mannheim's Sociology of Generations: An undervalued legacy. British Journal of Sociology. 45(3), 481495.

Prokopets, E. (2017). 3 Effective Tips for marketing to Millennials. [Web blog post]. Retrieved from https://www. huffingtonpost. com/elena-prokopets/3-effective-tips-for-mark_b_8418976.html?guccounter=1.

Rajnoha, R., Štefko, R., Merková, M. \& Dobrovič, J. (2016). Business intelligence as a key information and knowledge tool for strategic business performance management. Economics and management. 19(1), 183-202.

Rao, V. D. (2017). Building leaders for the next decade. Studies. Retrieved January, 12, 2019, from https://universumglobal. com/ building-leaders-next-decade/.

Rein, T. \& Purde, U. (2018). Sales cycle management. 48 p. Retrieved January, 12, 2019, from https://

www.pipedrive.com/en/resources/sales-cycle-management.

Robinson, M. T. (2017). The Generations. Which Generation are You? [Web blog post]. Retrieved from https://www. careerplanner. com/Career-Articles/Generations.cfm

Solomon, M., G. Bamossy, Asskegaard. S. \& Hogg, M. K. (2016). Consumer Behaviour: A European perspective. 6. Edition. London: Pearson Education. 736 p.

Schiffman, L., Hansen, H. \& Kanuk, L. (2012). Consumer Behaviour: A European Outlook. 2 Ed. London: Pearson Education

Standford, D. (2008). Examining the relationship between job satisfaction and customer satisfaction in a South africa firm. Gordon: Institute of Business Science.

Sunstein. C. R. (2016). Fifty Shades of Manipulation. Journal of Marketing Behavior. 1, 213-244

Štefko, R., Fedorko R. \& Bačík, R. (2014). The significance of internet marketing tools in terms of building a positive image of an higher education institution. Crafting global competitive economies: 2020 vision strategic planning \& smart implementation (1764-1772). Milan: International business information management association.

Williams, C. K. \& Page, R. A. (2011). Marketing to the Generations. Journal of Behavioral Studies in Business. 3(1), $37-53$.

Wroblewski, M. T. (2018). Generation X Consumer Behavior. [Web blog post]. Retrieved from

https://yourbusiness.azcentral.com/generation-X-consumer-behavior-9585.html 